maps indicating very broadly the areas where certain important crops are grown. There are also tables showing the incidence and relative importance of the different food-crops grown in the various territories, a classified list of the food plants of Africa, and a bibliography. As Mr. Wieschhoff, the Editor of the series, writes in his introduction, very little information is available about the food resources of Africa, "which makes the situation potentially dangerous. Not only might valuable food resources be ignored, but Africa's productivity might be over-estimated and lead to disastrous local famines if drained too much'.

The information assembled in this little book is therefore of great value and its usefulness as a basis for further investigation is clear. It is interesting to note (p. 8) that in the French African colonies "statistics in regard to the total yield of each important crop are prepared regularly ', as a result of the great interest taken by French administrative officers in problems of nutrition. In the British African colonies this has not hitherto been done, except as regards crops grown for export, though nutrition experts have for some years been urging the importance of such records and something has been done on these lines in Burma and in Malaya. Now that the Hot Springs Conference has directed public attention to the importance of nutrition it is to be hoped that further researches will be undertaken and the existing inadequate information supplemented.

\title{
Emslie Horniman Anthropological Scholarship Fund
}

The fund was created by the late $E$. J. Horniman in order to encourage scientific study of all that relates to the social, cultural, and physical characteristics and development of nonEuropean peoples; the Trustees of the fund are empowered to make such awards as are likely, in their opinion, to promote the objects of the fund. Awards will be made to graduates of Universities or to other persons approved by the Trustees, and will take the form of Studentships, tenable normally for not less than one year and not more than two at any recognized University in any part of the world which provides facilities for pursuing the objects of the fund. Candidates must be of British nationality, but there are no restrictions as to race, colour, sex, or religion. Applicants must submit proposals for a scheme of study, including provision for field-work. Holders of Studentships will be expected to comply with the regulations of the University to which they are attached, and to render progress reports to the Trustees when requested.

All inquiries should be addressed to: The Secretary to the Trustees, Emslie Horniman Anthropological Fund, Royal Anthropological Institute, 2 I Bedford Square, London, W.C. I.

\section{U.S.S.R. Academy of Sciences}

Trrs Institute has recently been able to get into touch with the Library of Social Sciences of the Academy of Sciences, Moscow; we have sent, at the request of the Director of the Library, a number of our publications and have received two issues of the Academy's monthly Journal World Economy and World Politics. We are hoping to get further information, particularly with regard to work done in the U.S.S.R. on Mass Education and development in the Asiatic Territories.

\section{Centre d'Études Ethnographiques d'A. E. F.}

A CENTRE for study and research directed to ethnographical problems in French Equatorial Africa has recently been established in Brazzaville. We are in correspondence with the Secretary, M. Trezenem, and hope to be able to publish at a later date some account of the Centre's activities and projects. 